Saudi Journal of Medical and Pharmaceutical Sciences

Abbreviated Key Title: Saudi J Med Pharm Sci

ISSN 2413-4929 (Print) |ISSN 2413-4910 (Online)

Scholars Middle East Publishers, Dubai, United Arab Emirates

Journal homepage: https://saudijournals.com/sjmps

Original Research Article

\title{
A Review Article on Genitourinary Malakoplakia after Kidney Transplantation
}

Suhail Khojah*

Department of Internal Medicine and Nephrology, King Abdulaziz University, Jeddah, Saudi Arabia

DOI: $10.36348 /$ sjmps.2020.v06i02.009 $\quad$ | Received: 03.02.2020 | Accepted: 15.02 .2020 | Published: 20.02 .2020

*Corresponding author: Suhail khojah

\section{Abstract}

Malakoplakia has been rarely reported in renal transplant recipients. We discuss two renal transplant recipients with malakoplakia involving renal allografts. Both transplant recipients were managed with reducing the doses of immunosuppressive medications and long-term oral antibiotic therapy. The renal allograft functions remained stable and imaging studies did not show progression of the disease. Our data suggest reducing the immunosuppression and longterm antimicrobial therapy to achieve long-term renal allograft survival.

Keywords: Transplantation, Urinary tract infections, Infectious diseases, Drugs.

Copyright @ 2020: This is an open-access article distributed under the terms of the Creative Commons Attribution license which permits unrestricted use, distribution, and reproduction in any medium for non-commercial use (NonCommercial, or CC-BY-NC) provided the original author and source are credited.

\section{INTRODUCTION}

Malakoplakia is a chronic inflammatory condition associated with gram negative bacterial infections [1]. It also appears to be associated with immunosuppressive therapy after organ transplantation although it can also occur in immunocompetent patients [1-2]. Morphologically, it is similar to a pseudotumor and commonly involves the urinary bladder and kidneys [1-4]. It is histologically characterized by MichaelisGutmann bodies [1-5]. Here, we present the outcome of two patients with malakoplakia following kidney transplantation. We also reviewed the literature on the management of malakoplakia after kidney transplantation.

\section{Case 1}

A 74-year old female received a deceased renal transplant in 2012. The underlying renal disease remained unclear before transplantation. She did not receive any immunosuppressive medication prior to transplantation. She received induction therapy at the time of transplantation with rabbit-antithymocyte globulin. Following operation, she maintained on immunosuppression therapy including tacrolimus (achieving trough levels $6-7 \mathrm{ng} / \mathrm{ml}$ in first year then 5 $\mathrm{ng} / \mathrm{ml}$ after that), mycophenolic sodium and prednisone (titrating down to $15 \mathrm{mg}$ every other day). She did not develop allograft rejection after transplantation. Her post-transplant baseline serum creatinine was 70 $\mu \mathrm{mol} / \mathrm{L}$. She developed multiple episodes of urinary tract infections (UTI) with $E$. coli during the first two years after transplantation. This microorganism was resistant to ampicillin, ciprofloxacin and trimethoprimsulfamethoxazole. She received several courses of treatment with nitrofurantoin, cefazolin and cephalexin. She also developed 2 episodes of UTI with Enterobacter aerognes which were treated with ciprofloxacin. This patient underwent investigation to rule out perirenal abscess. In 2013, following multiple episodes of urinary tract infections, the probable diagnosis of renal allograft abscess was made considering the result of computed tomography (CT) scan and technetium $99 \mathrm{~m}$ white blood cell scan. The CT scan of kidney allograft showed an abnormal soft tissue density with perinephric fluid with a size of $6.6 \mathrm{~cm} \mathrm{x}$ $5.2 \mathrm{~cm}$ in maximal axial dimension. It was difficult to differentiate between abscess and mass. However, the white blood cell scan suggested possible presence of an abscess at the superior aspect of the allograft. She underwent percutaneous drainage of the perinephric collection. Subsequently, the decision was made to obtain a kidney biopsy to rule out post-transplant lymphoproliferative disorder (PTLD). The percutaneous needle biopsy of the renal allograft revealed histologic characteristics that were consistent with malakoplakia without evidence of malignancy. There was a predominance of CD68-positive histiocytes containing abundant PAS positive granular material. There were also numerous pale concretions, which were positive for Von Kossa stain consistent with Michaelis Guttmann bodies (figure 1). Considering the result of biopsy, we modified immunosuppressive regimen as 
follows: tacrolimus does were reduced to achieve through level of 3-3.5 ng/ml. We also decreased the dose of mycophenolic acid by $50 \%$. We also reduced the dose of prednisone to $5 \mathrm{mg} /$ day. We started a course of oral antibiotic therapy including oral ciprofloxacin $250 \mathrm{mg}$ twice daily and amoxicillin-calvulanic acid 250 mg-125 mg twice daily for two weeks. We closely monitored allograft function. Subsequently, we continued oral amoxicillin-calvulanic acid as chronic suppressive therapy and discontinued ciprofloxacin. We monitored all side effects while the patient was on antibiotic. The renal transplant patient did not experience recurrence of symptomatic urinary tract infection for at least 4 years. Multiple follow- up renal transplant ultrasounds and abdominal CT revealed slowly reducing of the size of malakoplakia lesion in the transplant kidney. The most recent ultrasound study in 2018 showed no malakoplakia lesion, fluid collection or abscess. Her most recent tests in 2018 showed stable renal function with maintaining serum creatinine at 70 $80 \mu \mathrm{mol} / \mathrm{L}$.

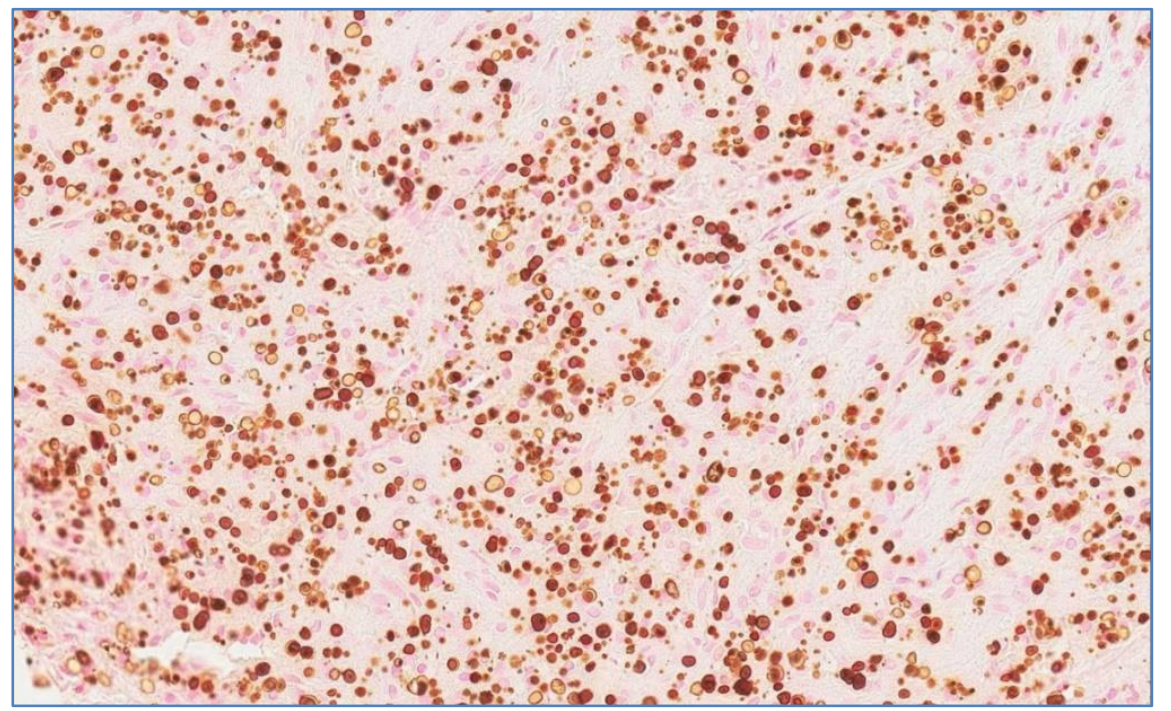

Fig-1: Von Kossa highlights intracytoplasmic (Michaelis Gutmann) bodies, a characteristic of malakoplakia

\section{Case 2}

A 62-year old female received renal transplant from a deceased donor in 2008. She did not undergo nephrectomy at the time of transplantation and her underlying renal disease remained unknown. She did not receive immunosuppressive medications prior to transplantation. She received induction immunosuppression with rabbit-antithymocyte globulin. She maintained on tacrolimus (target trough levels remained at $6-7 \mathrm{ng} / \mathrm{ml}$ in first year then $5 \mathrm{ng} / \mathrm{mL}$ after that), mycophenolic sodium and prednisone (titrating down to $15 \mathrm{mg}$ every other day). Postoperative course was complicated by delayed graft function. Her baseline serum creatinine level was $130 \mu \mathrm{mol} / \mathrm{L}$. Six years later, her serum creatinine started to rise with a peak level at $278 \mu \mathrm{mol} / \mathrm{L}$. She did not develop allograft rejection after transplantation. Multiple urine cultures did not reveal a pathogen and she remained asymptomatic. Ultrasonography and CT scan of transplant kidney were normal. A kidney transplant biopsy showed immunohistochemically evidence of malakoplakia including CD68 positive histiocytes (figure 2). Within the histiocytes there were PAS and Von Kossa positive intracytoplasmic bodies. In addition, it showed prominent neutrophilic casts raises the possibility of ascending infection. She received long-term antibiotic treatment associated with reducing the doses of the immunosuppressive medications. The dose of tacrolimus was decreased to achieve trough level of 3-3.5 ng/mL. We also decreased the dose of mycophenolic acid by $50 \%$ to 360 twice a day. We also reduced the dose of prednisone to $10 \mathrm{mg}$ every other day. She initially received treatment with oral levofloxacin $250 \mathrm{mg}$ Q48 and oral amoxicillincalvulanic acid 500mg-125 mg twice a day for 6 months. Subsequently, we discontinued levofloxacin and continued treatment with amoxicillin-calvulanic acid. We repeated her urine culture every month for 6 months which all came back negative. The kidney function slowly improved with reduction of baseline serum creatinine. Her most recent tests in 2018 showed stable renal function with maintaining serum creatinine at $180-190 \mu \mathrm{mol} / \mathrm{L}$. Graft function remained stable for the last three years. 


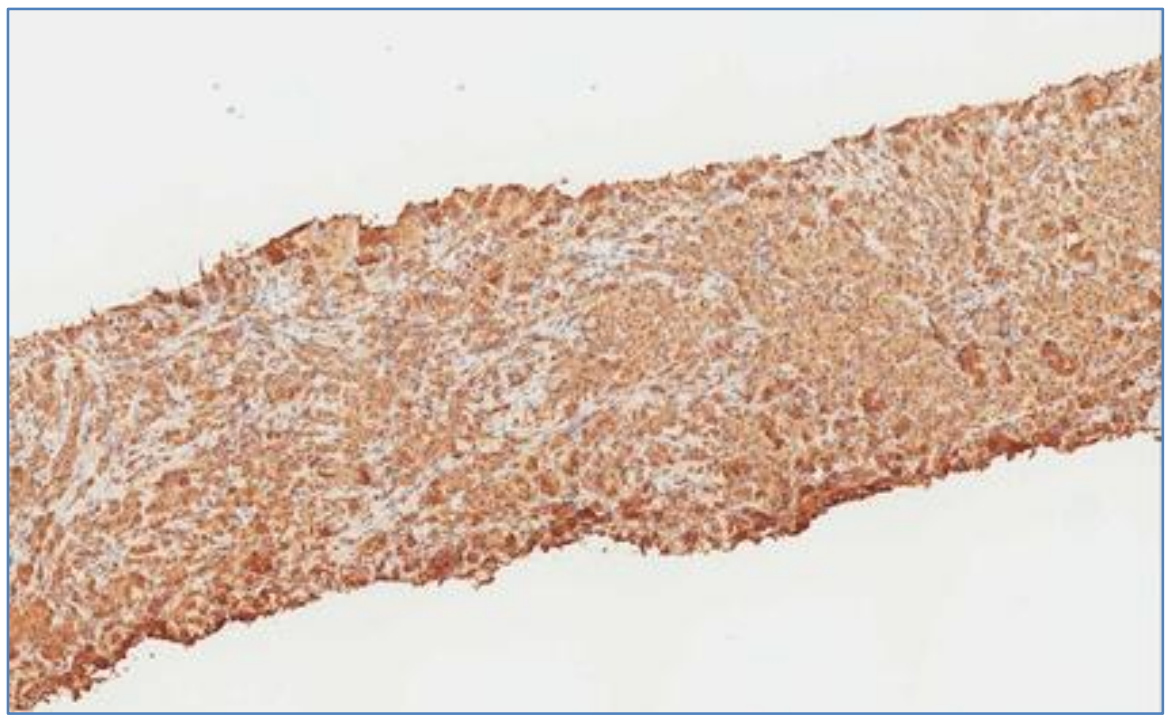

Fig-2: Renal biopsy shows abundant histiocytes, which are positive for CD68

\section{DISCUSSION}

Malakoplakia is a progressive disease with undetermined etiology. It mainly involves the genitourinary tract system. However, it has been reported to affect the skin, lungs, prostate and many other organs [3-6].

The most likely presentations of malakoplakia are recurrent urinary tract infection, acute kidney injury or both. E. coli is the most common microorganism that causes urine tract infection [5-7]. Other microorganisms have also been isolated [8]. Malakoplakia has been also shown to be associated with immunosuppression [1]. The cumulative immunosuppressive burden has been shown to be an important contributing factor for malakoplakia [9]. On the other hand, reducing of immunosuppression may cause improvement of malakoplakia. Biggar et al. demonstrated improvement of the phagocytic cell capacity after immunosuppressive therapy withdrawal [9-10].

The precise pathogenesis of malakoplakia is not entirely clear yet. Many theories explained different possible mechanisms for malakoplakia [8]. Severe suppression of cell mediated immunity including defect in macrophage function has been implicated in the pathogenesis. This defect leads to inability of monocytes and macrophages to digest the bacteria by phagocytosis. The defective lysosome function and low intracellular concentration of cyclic guanosine monophosphate (cGMP) in mononuclear cells are main abnormal functions of macrophages. This leads to calcified basophilic structures and the MichaelisGuttmann- bodies which are the fundamental histologic pictures for diagnosis malakoplakia [5-9].

The most important entities in the differential diagnosis of renal transplant malakoplakia are xanthogranulomatous pyelonephritis and post-transplant lymphoproliferative disorder. The diagnosis of malakoplakia can be determined only by histopathological findings demonstrating cytoplasmic Michaelis-Gutmann bodies. These inclusion bodies are stained with Perl's stain, periodic acid-Schiff and von Kossa stain. Immunohistochemically studies also show CD68 positive histiocytes [3-9].

Although the radiological appearance of posttransplant malakoplakia is generally non-specific, the imaging studies may suggest its etiology and also guide the sampling. On ultrasound, the most common feature of post-transplant malakoplakia is a diffuse enlargement of affected allograft. Less frequently, hypoechoic lesions and increased echogenicity of the kidney parenchyma may be detected. Magnetic resonance imaging (MRI) may demonstrate multiple small low signal nodules and nephromegaly. Computed tomography (CT) may also show enhancing solid or cystic components and nephromegaly $[11,12]$.

Renal parenchymal malakoplakia is associated with an aggressive course and significant morbidity in kidney transplant patients $[13,14]$. However, the outcome of post-transplant malakoplakia may improve with antibiotic therapy [7]. Although data related to the antibiotic treatment is limited, a good outcome may be achieved with immunosuppression reduction and administration of antimicrobial agents [5]. The antibiotics should penetrate the cell membrane and must have intracellular activity within the macrophages $[8$, 9]. Antibiotics other than the ones used in this study are trimethoprim- sulfamethoxazole (TMP-SMX) and gentamicin. There is no clear recommendation about the optimal duration for antibiotics regimen [7-12]. These therapeutic approaches to malakoplakia may improve patients and grafts survival. The aim of treatment is to augment macrophage function and facilitate host defense [7-15]. If the malakoplakia progresses, nephrectomy is required [14]. Both patients 
explained in this study were successfully treated with reduction of immunosuppression and long-term antibiotic therapy.

We reviewed all kidney transplant patients with malakoplakia who were reported since 2000 (table 1). Transplant nephrectomy was needed in one patient due to multiple abscesses involving the graft [4]. All patients were on immunosuppressive therapy including mycophenolic acid and tacrolimus except for one patient that the authors did not explain the immunosuppressive regimen in detail [4]. Only one patient with malakoplakia was a kidney-pancreas recipient [16]. The antibiotic regimens and the duration of treatment were variable. However, all patients who received a long-term antibiotic therapy had successful outcomes with preserved allograft function.

Table-1: Review of case reports dealing with the management of malakoplakia in renal transplant patients

\begin{tabular}{|c|c|c|c|c|c|c|}
\hline Studies & Age/sex & $\begin{array}{l}\text { Time from } \\
\text { transplant }\end{array}$ & $\begin{array}{l}\text { Immunosuppress } \\
\text { ion }\end{array}$ & Organism & Treatment /duration & outcome \\
\hline $\begin{array}{l}\text { Pusl et } \\
\text { al. [5] }\end{array}$ & $43 / F$ & 2 years & $\begin{array}{l}\text {-Mycophenolic } \\
\text { acid } \\
\text {-Tacrolimus }\end{array}$ & E. coli & $\begin{array}{l}\text { Antibiotic (not } \\
\text { specified)/ Not mention } \\
\text { duration }\end{array}$ & Cure \\
\hline $\begin{array}{l}\text { Puerto et } \\
\text { al. [4] }\end{array}$ & $45 / \mathrm{F}$ & 2 years & Not specific & E. coli & Nephrectomy & Graft loss \\
\hline $\begin{array}{l}\text { Augusto } \\
\text { et al. [3] }\end{array}$ & $56 / \mathrm{F}$ & 11 months & $\begin{array}{l}\text {-Mycophenolate } \\
\text { Mofetil } \\
\text {-Tacrolimus }\end{array}$ & E. coli & $\begin{array}{l}\text {-Decrease } \\
\text { immunosuppression } \\
\text {-Gentamicin for } 3 \text { days } \\
\text {-levofloxacin for } 10 \\
\text { weeks }\end{array}$ & $\begin{array}{l}\text { Salt losing } \\
\text { nephropathy }\end{array}$ \\
\hline $\begin{array}{l}\text { Honsova } \\
\text { et al. } \\
{[11]}\end{array}$ & $31 / \mathrm{F}$ & 3 years & $\begin{array}{l}\text {-Mycophenolate } \\
\text { Mofetil } \\
\text {-Tacrolimus }\end{array}$ & $\begin{array}{l}\text { E. coli and } \\
\text { staphylococcus } \\
\text { aureus }\end{array}$ & $\begin{array}{l}\text {-Decrease } \\
\text { immunosuppression } \\
\text {-quinolone/ not mention } \\
\text { duration }\end{array}$ & Cure \\
\hline $\begin{array}{l}\text { Graves et } \\
\text { al. [9] }\end{array}$ & $56 / \mathrm{F}$ & 2 years & $\begin{array}{l}\text {-Mycophenolate } \\
\text { Mofetil } \\
\text {-Tacrolimus } \\
\text {-prednisolone }\end{array}$ & $\begin{array}{l}\text { klebsiella } \\
\text { pneumoniae }\end{array}$ & $\begin{array}{l}\text {-Decrease } \\
\text { immunosuppression } \\
-12 \text { weeks intravenous } \\
\text { piperacillin/tazobactam } \\
\text { - oral faropenem and } \\
\text { fosfomycin for } 18 \\
\text { months }\end{array}$ & Cure \\
\hline $\begin{array}{l}\text { Neeto- } \\
\text { Rios et } \\
\text { al. [17] }\end{array}$ & $45 / \mathrm{F}$ & 2 years & $\begin{array}{l}\text {-Mycophenolate } \\
\text { sodium } \\
\text {-Tacrolimus } \\
\text {-Prednisone }\end{array}$ & E. coli & $\begin{array}{l}\text {-Decrease } \\
\text { immunosuppression } \\
\text {-Surgery } \\
\text {-TMP/SMX for } 12 \\
\text { weeks }\end{array}$ & Cure \\
\hline
\end{tabular}

\section{Conclusion}

The current level of evidence for the management of malakoplakia is limited. Although this is a rare disease, malakoplakia should be considered in renal transplant patients presenting with graft dysfunction with or without recurrent urinary tract infection [17]. Although imaging studies are helpful for the diagnosis, kidney biopsy is still the gold standard method. Immunosuppression reduction and long-term antibiotic therapy decrease the size of lesions. Renal transplant nephrectomy must be considered for refractory cases [3-4]. More studies are needed to know the optimum duration of therapy.

\section{REFERENCE}

1. McClure, J. (1983). Malakoplakia. J Pathol, 140(4):275-330.
2. Rubinson, R., Mendes, V.S., Sanchez, G., Costantini, S. (2012). Malakoplakia. Pediatr Dermatol, 29(4):541-3.

3. Augusto, J.F., Sayegh, J., Croue, A., Subra, J.F. (2008). Onno C. Renal transplant malakoplakia: case report and review of the literature. NDT Plus, 1(5):340-3.

4. Puerto, I.M., Mojarrieta, J.C., Martinez, I.B., Navarro, S. (2007). Renal malakoplakia as a pseudotumoral lesion in a renal transplant patient: a case report. Int J Urol, 14(7):655-7.

5. Pusl, T., Weiss, M., Hartmann, B., Wendler, T., Parhofer, K., Michaely, H. (2006). Malacoplakia in a renal transplant recipient. Eur J Intern Med. 17(2):133-5.

6. Behnes, C.L., Neumann, S., Schweyer, S., Radzun, H.J. (2012). Pleural malakoplakia caused by Rhodococcus equi infection in a patient after stem cell transplantation. Diagn Pathol. 7:20. 
7. Graves, A.L., Texler, M., Manning, L., Kulkarni, H. (2014). Successful treatment of renal allograft and bladder malakoplakia with minimization of immunosuppression and prolonged antibiotic therapy. Nephrology (Carlton). 19 Suppl 1:18-21.

8. Yousef, G.M., Naghibi, B., Hamodat, M.M. (2007). Malakoplakia outside the urinary tract. Arch Pathol Lab Med, 131(2):297-300.

9. Leão, C.A., Duarte, M.I., Gamba, C., Ramos, J.F., Rossi, F., Galvão, M.M. (2012). Malakoplakia after renal transplantation in the current era of immunosuppressive therapy: case report and literature review. Transpl Infect Dis, 14(6): E13741.

10. Biggar, W.D., Crawford, L., Cardella, C., Bear, R.A., Gladman, D., Reynolds, W.J. (1985). Malakoplakia and immunosuppressive therapy. Reversal of clinical and leukocyte abnormalities after withdrawal of prednisone and azathioprine. Am J Pathol, 119(1):5-11.

11. Zimina, O.G., Rezun, S., Armao, D., Braga, L., Semelka, R.C. (2002). Renal malacoplakia: demonstration by MR imaging. Magn Reson Imaging, 20(8):611-4.

12. Nieto-Ríos, J.F., Ramírez, I., Zuluaga-Quintero, M., Serna-Higuita, L.M., Gaviria-Gil, F., Velez-
Hoyos, A. (2017). Malakoplakia after kidney transplantation: Case report and literature review. Transpl Infect Dis.

13. Stern, S.C., Lakhani, S., Morgan, S.H. (1994). Renal allograft dysfunction due to vesicoureteric obstruction by nodular malakoplakia. Nephrol Dial Transplant, 9(8):1188-90.

14. McKenzie, K.J., More, I.A. (1996). Nonprogressive malakoplakia in a live donor renal allograft. Histopathology, 28(3):274-6.

15. Shah, M.B., Sundararajan, S., Crawford, C.V., Hartono, C. (2010). Malakoplakia-induced diarrhea in a kidney transplant recipient. Transplantation, 90(4):461-2.

16. Honsova, E., Lodererova, A., Slatinska, J., Boucek, P. (2012). Cured malakoplakia of the renal allograft followed by long-term good function: a case report. Biomed Pap Med Fac Univ Palacky Olomouc Czech Repub, 156(2):180-2.

17. Merritt, A.J., Thiryayi, S.A., Rana, D.N. (2014). Malakoplakia diagnosed by fine needle aspiration (FNA) and liquid-based cytology (LBC) presenting as a pararenal mass in a transplant kidney. Cytopathology, 25(4):276-7. 